\title{
The bank vole Myodes glareolus (Arvicolinae, Rodentia) of southern European Russia: distribution and mitochondrial variation
}

\author{
Valeriy V. Stakheev*, Ekaterina V. Obolenskaya, Elena S. Fomina \\ \& Nikita V. Panasyuk
}

\begin{abstract}
The distribution and genetic polymorphism of the bank vole in the south of its distribution range in European Russia are discussed. Myodes glareolus from this territory displays lower values of haplotype diversity than voles from the central parts of the distribution range; while nucleotide diversity is comparable in both territories. The results suggest the long-term existence of fragmented populations of the bank vole in southern European Russia, as well as negative periods in the history of populations.
\end{abstract}

How to cite this article: Stakheev V.V., Obolenskaya E.V., Fomina E.S., Panasyuk N.V. 2019. The bank vole Myodes glareolus (Arvicolinae, Rodentia) of southern European Russia: distribution and mitochondrial variation // Russian J. Theriol. Vol.18. No.2. P.115-119. doi: 10.15298/rusjtheriol.18.2.07

KEY WORDS: the bank vole, genetic polymorphism, south of European Russia, isolation.

Valeriy V.Stakheev [stvaleriy@yandex.ru], Elena S. Fomina \& Nikita V. Panasyuk, Federal Research Centre, the Southern Scientific Centre of the Russian Academy of Sciences, Chekhov str. 41, Rostov-on-Don 344006, Russia; Ekaterina V. Obolenskaya [obolenskaya@zmmu.msu.ru], Zoological Museum of Moscow State University, Bolshaya Nikitskaya 6, Moscow 125009, Russia.

\section{Рыжая полевка Myodes glareolus (Arvicolinae, Rodentia) на юге европейской части России: распространение и генетическая изменчивость}

\section{В.В. Стахеев, Е.В. Оболенская, Е.С. Фомина, Н.В. Панасюк}

\begin{abstract}
РЕЗЮМЕ. Рассмотрены вопросы распространения и генетического полиморфизма рыжей полевки на юге своего ареала в пределах европейской части России. Показано, что Myodes glareolus на рассматриваемой территории обладает более низкими значениями галотипического разнообразия, чем популяции в центральной части ареала, демонстрируя при этом довольно высокий уровень нуклеотидного полиморфизма. Полученные данные позволяют говорить о продолжительности обитания рыжей полевки в фрагментированных местообитаниях на юге европейской части России и существовании негативных периодов в прошлом.
\end{abstract}

КЛЮЧЕВЫЕ СЛОВА: рыжая полевка, генетический полиморфизм, юг России, изоляция.

The bank vole Myodes glareolus Schreber, 1780 is a widespread species and a typical inhabitant of broadleaved and mixed forests. The species occurs across almost the whole of Europe from the British Isles in the west to Central Siberia in the east (Abramson \& Lissovsky, 2012). In the European part of Russia, the southern limit of distribution is situated in the Rostov and Volgograd regions.

The bank vole is a well-studied species with regards to many aspects of its biology: morphology, ecology, taxonomy, phylogeography, palaeontology, etc. Nevertheless, this does not apply to bank vole populations at the southern limit of the distribution in European Russia. The general patterns of occurrence are known only roughly in this region: reproductive biology and habitat preferences

\footnotetext{
* Corresponding author
}

have not yet been studied. There is no information on the vole's phylogenetic characteristics. One of the reasons for this lack of information is the sporadic distribution of the bank vole in the southern parts of the Russian Plain.

The goal of this short note is to describe the geographical distribution, genetic diversity and population structure of the bank vole in the southern Russian Plain. This information allows us to theorise on some historical aspects of the population of the bank vole.

We studied eight voles from three districts of the Rostov Region: Sholokhovskiy, Verkhnedonskoy and Belokalitvenskiy (Table 1). All localities are stored in the Mammals of Russia database http://rusmam.ru/. In addition to newly processed specimens, GenBank data was also included (Table 1).

Total genomic DNA was extracted using the standard phenol-chloroform method (Maniatis et al., 1984) 
Table 1. Material for the minimum spanning network.

\begin{tabular}{|c|c|}
\hline Regions & GenBank IDs \\
\hline $\begin{array}{l}\text { Northern, Central and Eastern } \\
\text { Europe, Russia }\end{array}$ & $\begin{array}{c}\text { AF318585, AF367078, AF367084, DQ472231, DQ472246, DQ472263, DQ472316, } \\
\text { DQ472337, DQ472340, DQ472343, FJ881441, FJ881444, FJ881447, FJ881457, } \\
\text { FJ881459, FJ881460, FJ881461, FJ881463, FJ881464, FJ881466, FJ881467, } \\
\text { FJ881472, FJ881475, FJ881478, FJ881489, JX477265, JX477267, JX477269, } \\
\text { JX477270, JX477271, JX477272, JX477273, JX477274, JX477275, JX477276, } \\
\text { JX477277, JX477278, JX477279, JX477280, JX477281, JX477282, JX477285, } \\
\text { JX477287, JX477289, JX477290, JX477292, JX477293, JX477295, JX477296, } \\
\text { JX477298, JX477299, JX477302, JX477303, JX477304, JX477310, JX477311, } \\
\text { KJ612471, KJ612478, KJ612479, KJ612482, KJ612484, KJ612498, KJ612499, } \\
\text { KJ612500, KJ612501, KJ612504, KJ612510, KJ612511, KJ612512, KM892810, } \\
\text { KM892811, KM892815, KM892818, KM892819, KM892820, KM892821, } \\
\text { KM892822, KM892826, KM892830, KT119386 }\end{array}$ \\
\hline south of Eastern Europe & DQ472327, KM892812, KM892813, KM892814, KM892816 \\
\hline Southern Europe & $\begin{array}{l}\text { KM892809, KM892825, KM892834, KM892836, KM892837, KM892838, } \\
\text { KM892839, KM892840 }\end{array}$ \\
\hline British Isles & KM892827, KM892828, KM892829, KM892831 \\
\hline Asian part of Turkey & KM892817 \\
\hline $\begin{array}{l}\text { Southern European Russia, Ros- } \\
\text { tov Region } \\
\text { (our data) }\end{array}$ & $\begin{array}{c}\text { Sholokhovskiy District, Gorokhovskiy Village; } \\
\text { Sholokhovskiy District, Gorokhovskiy Village; } \\
\text { Sholokhovskiy District, Veshenskaya Village; } \\
\text { Sholokhovskiy District, Krasnoyarovskiy Village; } \\
\text { Sholokhovskiy District, Krasnoyarovskiy Village; } \\
\text { Belaya Kalitva Town; } \\
\text { Belaya Kalitva Town; } \\
\text { Sovetskiy District, Novoryabukhin Village }\end{array}$ \\
\hline
\end{tabular}

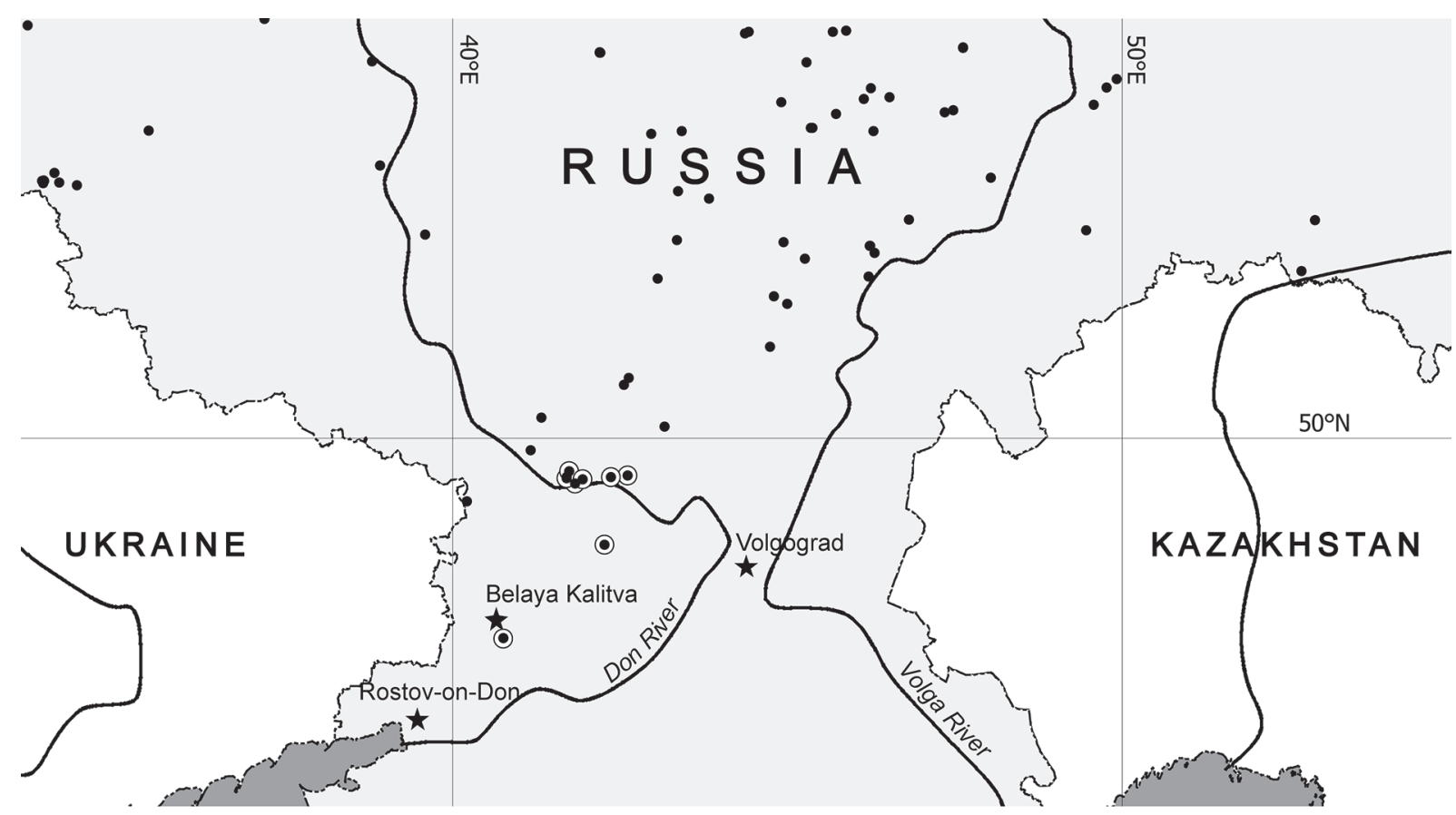

Fig. 1. Map of the distribution of the bank vole in southern European Russia (black dots) and geographical position of studied material (black dots in white circles). 
Table 2. Genetic diversity of the bank vole.

\begin{tabular}{|c|c|c|c|c|}
\hline Regions & $n$ & $\begin{array}{c}\text { Haplotype diversity } \\
\text { Hd } \pm \text { SD }\end{array}$ & $\begin{array}{c}\text { Nucleotyde diversity } \\
\pi \pm \text { SD }\end{array}$ & Data source \\
\hline Rostov Region & 8 & $0.79 \pm 0.02$ & $0.56 \pm 0.003$ & Our data \\
\hline $\begin{array}{c}\text { South-west of European Russia } \\
\text { (south of } 60^{\circ} \mathrm{N} \text { ) }\end{array}$ & 17 & $0.92 \pm 0.03$ & $0.46 \pm 0.03$ & Abramson et al., 2009 \\
\hline $\begin{array}{c}\text { South-east of European Russia } \\
\text { and Middle Ural }\end{array}$ & 27 & $0.95 \pm 0.03$ & $0.61 \pm 0.02$ & Abramson et al., 2009 \\
\hline North-west of European Russia & 16 & $0.96 \pm 0.01$ & $0.37 \pm 0.02$ & Abramson et al., 2009 \\
\hline
\end{tabular}

with addition of proteinase $\mathrm{K}$ and dithiothreitol. A 536 bp fragment of mitochondrial cytochrome $b$ gene was amplified using PCR. Each PCR had a total volume of $50 \mu \mathrm{l}$ and contained $1.5 \mu \mathrm{l}$ of $\mathrm{MgCl}_{2}, 5 \mu \mathrm{M}$ of each primer, $200 \mu \mathrm{M}$ dNTP, $10 \mu \mathrm{M}$ Tris- $\mathrm{HCl}(\mathrm{pH} 8.3), 50 \mu \mathrm{M}$ $\mathrm{KCl}, 5-10 \mathrm{ng}(1-2 \mu \mathrm{l})$ of genomic DNA, and 1.5 units of Taq DNA polymerase. The following primer pair was used: 5'-AGTAGACAAGGCCACCCTCA-3' and 5'-TGGTTTACAAGACCAGCGTAA-3'. Amplification was performed using the Mastercycler Gradient (Eppendorf) under the following conditions: $94{ }^{\circ} \mathrm{C}$ for $4 \mathrm{~min}$; 36 cycles of $94{ }^{\circ} \mathrm{C}$ for $40 \mathrm{sec}, 58{ }^{\circ} \mathrm{C}$ for $40 \mathrm{sec}$ and 72
${ }^{\circ} \mathrm{C}$ for $40 \mathrm{sec}$, and a final elongation step at $72^{\circ} \mathrm{C}$ for 15 min. PCR products were analysed on a $2 \%$ agarose gel with ethidium bromide using the Molecular Imager Gel Doc XR System (Bio-Rad, USA).

DNA sequencing was performed with the ABI PRISM 3500 (Applied Biosystems, USA) and "DNA Sequencing Analysis Software", ver. 3.7. Sequences of $536 \mathrm{bp}$ were aligned using the BioEdit Sequence Alignment Editor ver. 7.0.5.3. Inter-sequence differences were evaluated on the basis of Kimura $2 p$ model (Kimura, 1980) in MEGA ver. 5.1 (Tamura et al., 2011). Minimum spanning network of haplotypes (Bandelt et

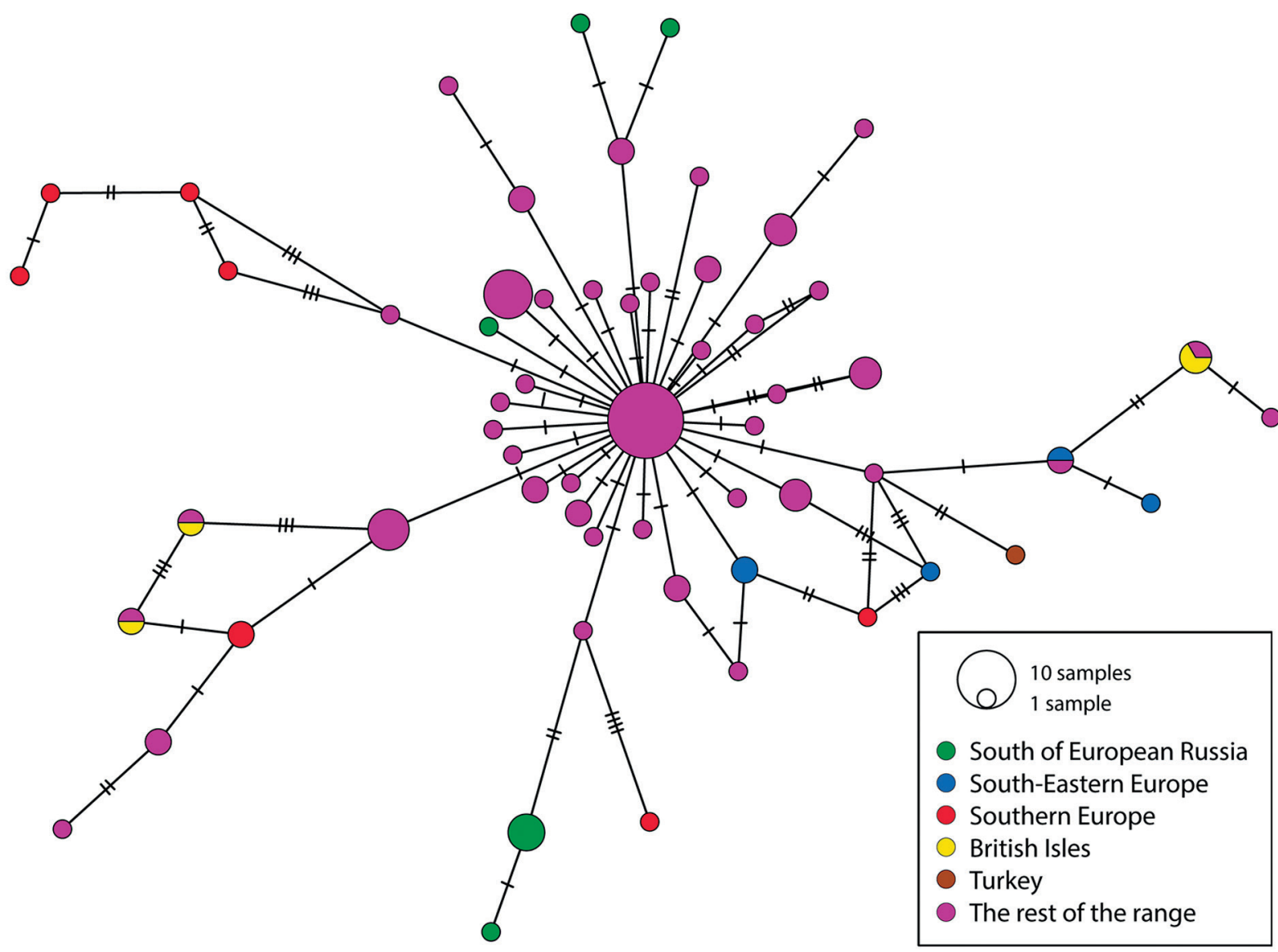

Fig. 2. Minimum spanning network of cytochrome $b$ fragments of the bank vole. 
al., 1999) was constructed in PopART 1.7 (Leigh \& Bryant, 2015). Genetic diversity was calculated using DnaSP ver. 6.10 .00 (Rozas et al., 2017).

Eight new sequences formed five haplotypes with eight polymorphic positions, four of which were informative. The haplotype diversity was low at $0.79 \pm 0.02$, while the nucleotide diversity $(0.56 \pm 0.003)$, in contrast, was higher than in the population of $M$. glareolus from the centre of the distribution range (Table 2). Pairwise genetic distances between the newly obtained sequences were quite large $(0.93-1.12 \%)$.

The bank vole was first registered in Rostov Region by T.I. Kritskaya (1962) in the steppe ravine forests of the Verkhnedonskoy District near Verkhne-Lopatinskiy Village. Later the species was found also in the Sholokhovskiy and Chertkovskiy districts of the Rostov Region (Shilova et al., 1994; Kolesnikov \& Belaya, 2002). Additionally, we found the bank vole in Belokalitvenskiy, Oblivskiy and Sovetskiy districts.

The phylogeographic structure of the bank vole is well studied, mainly on the basis of the cytochrome $b$ gene (Kotlík et al., 2006; Abramson et al., 2009; Melnikova, 2014; Filipi et al., 2015). The majority of investigators agree on six mitochondrial lineages across the whole distribution range of $M$. glareolus. Two of them are known to be from Russian territory, excluding the southern Russian Plain that is still unstudied. The mainland population of the bank vole is weakly differentiated, and phylogenetic trees lack good support for intra-species clades.

The minimum spanning network forms a star-like structure with a well-recognised central haplotype and a number of more or less differentiated branches (Fig. $1)$. The central haplotype was found in voles from Finland, Poland and Ukraine. The most distant branches are formed by haplotypes from Balkan Peninsula, southern Europe (France and Spain), Slovakia and Scandinavia. The bank voles from the left bank of the Don River in the Rostov Region also form a separate branch together with several haplotypes from Finland and Ukraine. Voles from the right (southern) bank of the Don River form another branch together with a haplotype from Ukraine.

Bank voles of southern European Russia have lower haplotype diversity than populations in central parts of the range (Table 1), while their nucleotide diversity is relatively high. Such patterns could be explained by a periodic decrease in the number of highly fragmented habitats, which is realistic for the marginal population. It is likely this decrease did not lead to extinction in the various forest fragments, thus each of them was a shelter for several haplotypes. Such forest refugia are known for southern European Russia during the Late PleistoceneEarly Holocene (Markova et al., 2008). Comparable values of nucleotide diversity in northern European Russia could be also explained by the conservation of diversity in forest refugia at the Pleistocene-Holocene transition period (Väliranta et al., 2011).
Our results are undoubtedly preliminary. Nevertheless, we hypothesise that investigating the southern, marginal populations of the bank vole will shed light onto the Late Pleistocene dispersion history of the species.

ACKNOWLEDGEMENTS. This study supported by the Russian Foundation for Basic Research, grant No. 18-04-00369.

\section{References}

Abramson N.I. \& Lissovsky A.A. 2012. Subfamily Arvicolinae // Pavlinov I.Ya. \& Lissovsky A.A. (eds.). The Mammals of Russia: a Taxonomic and Geographic Reference. Archives of Zoological Museum of Moscow State University. Moscow: KMK Scientific Press. Vol.52. P.127-141.

Abramson N.I., Rodchenkova E.N. \& Kostygov A.Yu. 2009. Genetic variation and phylogeography of the bank vole (Clethrionomys glareolus, Arvicolinae, Rodentia) in Russia with special reference to the introgression of the mtDNA of a closely related species, red-backed vole ( $\mathrm{Cl}$. rutilus $)$ // Russian Journal of Genetics. Vol.45. No.5. P.533-545.

Bandelt H.-J., Forster P. \& Röhl A. 1999. Median-joining networks for inferring intraspecific phylogenies // Molecular Biology and Evolution. Vol.16. No.1. P.37-48.

Filipi K., Marková S., Searle J.B. \& Kotlík P. 2015. Mitogenomic phylogenetics of the bank vole Clethrionomys glareolus, a model system for studying end-glacial colonization of Europe // Molecular Phylogenetics and Evolution. Vol.82. P.245-257.

Kimura M. 1980. A simple method for estimating evolutionary rates of base substitutions through comparative studies of nucleotide sequences // Journal of Molecular Evolution. Vol.16. No.2. P.111-120.

Kolesnikov K. \& Belaya A. 2002. [Materials on rodent fauna of the north of the Rostov Region] // Veshenskii Vestnik. No.2. P.196-203 [in Russian].

Kotlík P., Deffontaine V., Mascheretti S., Zima J., Michaux J.R. \& Searle J.B. 2006. A northern glacial refugium for bank voles (Clethrionomys glareolus) // Proceedings of the National Academy of Sciences of the USA. Vol.103. No.40. P.14860-14864.

Kritskaya T.I. 1962. [About the presence of the bank vole (Clethrionomys glareolus istericus Mull.) in the Rostov Region] // Zoologicheskii Zhurnal. Vol.41. No.6. P.956 [in Russian].

Leigh J.W. \& Bryant D. 2015. PopART: full-feature software for haplotype network construction // Methods in Ecology and Evolution. Vol.6. No.9. P.1110-1116.

Maniatis T., Fritsch E. \& Sambrook J. 1984. [Molecular Cloning]. Moscow: Mir. 474 p. [In Russian].

Markova A.K., Van Kolfschoten T., Bohncke S., Kosintsev P.A., Mol J., Puzachenko A.Yu., Simakova A.N., Smirnov N.G., Verpoorte A. \& Golovachev I.B. 2008. [Evolution of the European Ecosystems During Pleistocene-Holocene Transition (24-8 kyr BP)]. Moscow: KMK Scientific Press. 556 p. [In Russian, with English summary].

Melnikova E.N. 2014. [Phylogeography, history of settlement, and the intraspecific structure of the European red-backed vole (Rodentia, Cricetidae)]. PhD Thesis. Saint Petersburg: Zoological Institute RAS. 23 p. [In Russian]. 
Rozas J., Ferrer-Mata A., Sánchez-DelBarrio J.C., GuiraoRico S., Librado P., Ramos-Onsins S.E. \& Sánchez-Gracia A. 2017. DnaSP 6: DNA Sequence Polymorphism Analysis of large data sets // Molecular Biology and Evolution. Vol.34. No.12. P.3299-3302.

Shilova S.A., Kalinin A.A., Shchipanov N.A., Savinetskaya L.E. \& Oleynichenko V.Yu. 1994. [Anthropogenic transformation of small mammals north of the Rostov Region] // Zoologicheskii Zhurnal. Vol.73. No.3. P.98-103 [in Russian].
Tamura K., Peterson D., Peterson N., Stecher G., Nei M. \& Kumar S. 2011. MEGA5: Molecular Evolutionary Genetics Analysis using maximum likelihood, evolutionary distance, and maximum parsimony methods // Molecular Biology and Evolution. Vol.28. No.10. P.2731-2739.

Väliranta M., Kaakinen A., Kuhry P., Kultti S., Salonen J.S. \& Seppä H. 2011. Scattered late-glacial and early Holocene tree populations as dispersal nuclei for forest development in north-eastern European Russia // Journal of Biogeography. Vol.38. No.5. P.922-932. 